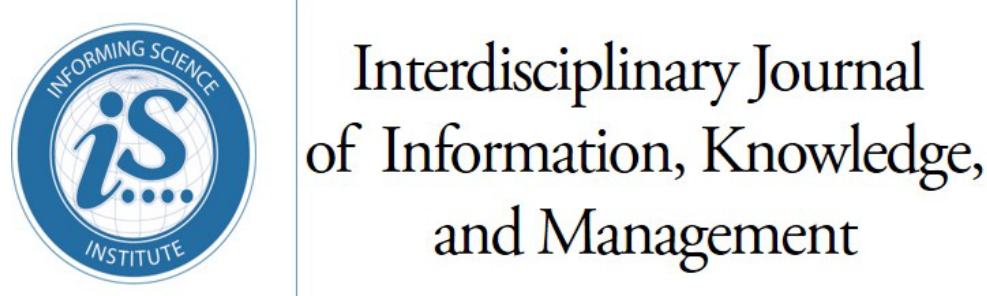

An Official Publication

of the Informing Science Institute

InformingScience.org

IJIKM.org

Volume 16, 2021

\title{
Transition to a Competitive Consultant SELECTION METHOD: A CASE STUdY OF A PubliC AGENCY IN ISRAEL
}

$\begin{array}{lll}\text { Amichai Mitelman } & \text { Ariel University, Ariel, Israel } & \text { amichaim@ariel.ac.il } \\ \text { Yahel Giat* } & \text { Jerusalem College of Technology, } & \text { yahel@jct.ac.il } \\ \text { * Corresponding author } & & \end{array}$

\begin{abstract}
Aim/Purpose

This paper reports a case study of organizational transition from a non-competitive selection method to a novel bidding method for the selection of consultants in the Architectural and Engineering (A/E) industry.

Background

Public procurement agencies are increasingly relying on external consultants for the design of construction projects. Consultant selection can be based on either competitive bidding, or quality-based criteria, or some combination between these two approaches.
\end{abstract}

Methodology

Different sources of information were reviewed: internal documents, and quantitative data from the enterprise software platform (ERP). In addition, informal and unstructured interviews were conducted with relevant officials.

Contribution

As there are mixed opinions in the scientific literature regarding the use of competitive bidding for the selection of consultants in the A/E industry, this paper contributes a detailed review of a transition to a competitive selection method and provides a financial and qualitative comparison between the two methods. In addition, the method implemented is novel, as it delegates most of the responsibility of hiring and managing consultants to one main contractor.

Findings

While the new selection method was intended to reduce bureaucratic overload, it has unexpectedly also succeeded to reduce costs as well.

Recommendations It may be more efficient and profitable to adopt the selection method described for Practitioners in this study.

Accepting Editor Christine Nya-Ling TAN | Received: October 21, 2021 | Revised: December 10, December 13, 2021 | Accepted: December 16, 2021.

Cite as: Mitelman, A., \& Giat, Y. (2021). Transition to a competitive consultant selection method: A case study of a public agency in Israel. Interdisciplinary Journal of Information, Knowledge, and Management, 16, 491-503. https://doi.org/10.28945/4891

(CC BY-NC 4.0) This article is licensed to you under a Creative Commons Attribution-NonCommercial 4.0 International License. When you copy and redistribute this paper in full or in part, you need to provide proper attribution to it to ensure that others can later locate this work (and to ensure that others do not accuse you of plagiarism). You may (and we encourage you to) adapt, remix, transform, and build upon the material for any non-commercial purposes. This license does not permit you to use this material for commercial purposes. 
Recommendations Similar methods can be applied to other industries successfully.

for Researchers

Impact on Society Our method was applied in a public organization and resulted in a better outcome, both financial and managerial. Adopting this approach can benefit public budgets.

Future Research The selection, data storage, and analysis methods are interrelated components. Future analysis of these components can help better shape the consultant selection process.

Keywords

A/E services, consultant selection, public procurement, design management, team building

\section{INTRODUCTION}

The design of construction projects regularly requires hiring multiple firms that act together as a design team that provides architectural and engineering (A/E) services. It is of great importance to select a competent design team, as the inadequate design has been found to be a major contributor to project delays and cost overruns (Han et al., 2013). In the private sector, clients regularly select consultants based on previous experience and recommendations (West, 1997). In contrast, procurement processes in public organizations are constrained by local laws and regulations that dictate formal and objective selection criteria.

The subject of consultant selection has been the interest of various researchers (Christodoulou et al., 2004; Ling, 2004; Wong et al., 2001). In practice, two opposite approaches can be identified (Sporrong, 2011):

1. Competitive (price-based) selection: The consultant with the most competitive fee offer is typically selected and paid according to their offer.

2. Non-competitive selection (NCS): Consultants are selected based on client choice (usually based on past experience or reputation). The consultants are paid according to a standard fee schedule.

The rationale for the competitive bid approach is simple. Tight public budgets dictate that spending is minimized, and this can be achieved through competitive pricing. Moreover, this method is presumably fairer and objective. The main argument in support of non-competitive selection is that architects and engineers are licensed professionals acting as representatives of the public, and therefore should not be compared to commodities (American Society of Civil Engineers [ASCE], 2012). These professions should be viewed similarly to the medical practice; just as patients choose their doctors mainly on the basis of quality and trust, so should consultants be selected based on these attributes and not according to the cost criterion (Christodoulou et al., 2004). Additionally, it can be argued that design costs are an investment that contributes to the final value of a project, and therefore a substantial increase in project value due to quality design considerably outweighs the higher design costs.

The Department of Engineering and Construction (DEC) is a large governmental agency in Israel responsible for the design, construction, and maintenance of several facilities. DEC plays a key role in the national construction industry, with a very large annual budget for construction. For many years, DEC selected consultants using an NCS approach. In 2013, a novel consultant selection method was developed, and the organization implemented a competitive bid process for the hiring of $\mathrm{A} / \mathrm{E}$ design team leaders. During the years following this development up to the present, different insights have been gained, and procedural modifications were made accordingly.

The paper is organized as follows. The next section reviews the current research in the field of $\mathrm{A} / \mathrm{E}$ consultant selection. Following the literature review, a methodology section describes the data 
selection process and the background of the case study. The subsequent two sections identify the problems with the current method and propose changes to it. These sections are followed by a quantitative and qualitative description and analysis of the outcomes of the selection method change. The final section concludes and describes the study's limitations.

\section{LITERATURE REVIEW}

For the purposes of determining the payment for A/E services, different fee curves have been developed. Additionally, many procurement agencies published standards that tie between the level of the consultancy fees and the construction costs; for example, the updated manual published by the Committee on Professional Practice of the American Society of Civil Engineers (ASCE, 2012). The question of whether these standards reasonably reflect the state of consultant practice and costs has been much debated (Carr \& Beyor, 2005).

The question of whether organizations should apply competitive bidding methods for A/E selection has long been debated. Sporrong (2011) has argued that procurement agencies have limited ability to assess consultant skill and competence. Indeed, the need for an A/E prequalification model was argued by Shash and Ajairi (2021). Manzoni and Volker (2017) studied consultant selection in the context of creative professionals and discussed how competition increases the tension between economic and artistic performance. In practice, many organizations implement selection methods that lie in between competitive price-based selection and NCS. A notable example is from the US; in 1972, a federal law (commonly referred to as the Brooks Act) was passed in the U.S. Congress and required that $\mathrm{A} / \mathrm{E}$ services in the public sector be hired according to a qualifications-based approach (QBS). According to QBS, tenders for consultant services are done in two major steps. In the first step, consultants submit their qualifications for the service and the public agency selects the most qualified submission. In the second step, fees are negotiated. Many researchers are critical of QBS. For example, Feldmann et al. (2008) argue that under QBS, organizations do not have leverage for cost containment because they have already agreed to contract with a specific A/E professional. Christodoulou et al. (2004) argued that when compared against pure competitive bidding, the benefits of QBS outweigh the additional costs spent on A/E services.

In recent years, the global trend has been to abolish fixed professional fees to increase competition. Research on the benefits of this trend resulted in mixed conclusions. For example, Laryea et al. (2020) studied the effects of a decision by South Africa's Competition Commission that dictated a competitive selection process for A/E services. They concluded that this ruling did not lead to a decline in the quality of work. In contrast, Akampurira and Windapo (2018) concluded that competitive bidding and low design fees adversely affected the quality of design documents in South Africa. Similarly, Minato (2003) investigated the quality of design documents in the Japanese construction industry and concluded that by reducing design fees, clients end up losing money due to the implications of low-quality planning. A study of the municipal level in Sweden showed that low price is the most important factor for consultant selection (Sporrong, 2011). A later follow-up study revealed that preferences vary within these municipalities, where technical construction-related staff prefer lowcost methods, while procurement staff favor more advanced selection methods (Sporrong \& Kadefors, 2014). Ogbu and Imafidon (2021) find that service delivery approaches are the criteria most associated with client satisfaction.

In general, over the past decades, the public sector has been increasingly more reliant on external consultants (Steiner et al., 2018). Despite this growing dependency, there is little research studying the processes and effects of external consultancy management in the public sector (Steiner et al., 2018). Although the question of consultant selection method has a crucial impact on public utility, the research regarding this subject is relatively scant. 


\section{METHODOLOGY}

Löwstedt and Räisänen (2012) conducted a longitudinal interpretative case study of change in a large construction company. They compared narratives from formal documents and in-depth interviews collected at the middle-management level and found significant differences between the two. Consequently, they concluded that to better understand organizational change, both narratives should be considered. Consistent with this argument, for the case study reported in this paper, data was gathered from three distinct sources:

1. Internal documents and presentations related to organizational change.

2. Informal and unstructured conversations with relevant officials conducted periodically between the years 2016-2021.

3. Quantitative data from DEC's enterprise planning software platform (ERP).

Conversations were conducted with a senior member of the procurement branch and a member of the task committee, who also gathered and shared with us the relevant documents. The changes in PM personal in DEC are highly frequent; hence, it was difficult to maintain the consistency of interviewees. However, informal conversations with various PMs were conducted over the years, in order to receive their opinions on the selection method, and the manner in which it affects project performance.

As discussed in the literature review, there are mixed opinions and data regarding the optimal method for consultant selection. Comparing data from different methods applied in different organizations, although important, poses the problem of invalid comparisons due to different environments and conditions. Therefore, an in-depth review of a single case study allows for a better comparison of outcomes.

\section{BACKGROUND}

Projects managed by DEC comprise various types of construction operations (e.g. new buildings, renovations, infrastructure projects). These projects are managed primarily by civil engineers and architects, who act as project managers (PMs). Nearly all design and construction services are outsourced by DEC to private firms and contractors.

Local regulations of public agencies distinguish between the hiring of consultancy services and the hiring of construction services. For construction services, a competitive bid selection process is required. Hence, all construction services in DEC are awarded to private contractors via a rigorous tendering process. As in the majority of public organizations (Awwad \& Ammoury, 2019), the most common form of bidding used in DEC is the low-bid method.

In contrast, the hiring of consultancy services is exempt from a public tendering process and allows for the application of an NCS approach. The following general procedure has been applied in DEC for consultant selection. The PM lists their preferred consultants, from a list of pre-approved consultants by DEC. A decisions committee must then decide whether to approve the PM's preferred consultants. The committee comprises representatives of DEC as well as other public and private representatives. These guidelines aim to grant equal opportunity and transparency.

Public agencies that subscribe to the NCS approach commonly develop or adopt A/E fee guidelines and calculators. A/E fees are typically computed as a percentage of actual construction costs, multiplied by different factors which reflect predominantly upon project complexity (Feldmann et al., 2008). Similarly, DEC has developed an A/E fee standard of its own. The standard lists the fees, scope of services, and general regulations pertinent to the work of the consultants.

Over the years, the DEC A/E fee standard was used for countless projects. Nevertheless, managerial discussions debated whether the consultant selection method should be modified or changed altogether. Hence, a task committee was established to analyze the selection process and recommend 
changes if needed. This committee was led by the head of the procurement branch and consisted of officials from this branch and a number of PMs. This allowed a wide perspective that accounts for both procedural processes led by the procurement branch, as well as the PMs' perspective, as those who interact directly with the consultants and are committed to project quality and deadlines. Accordingly, this case study's main research questions are:

1. What are the main issues with the implementation of the NCS selection process in DEC?

2. Is there an alternative selection process that can overcome these problems?

In the next section, we describe the analysis of the NCS and the proposed changes to the selection process. These changes were initiated in 2012 and over the years have been re-examined. This leads to our final research question:

3. What are the outcomes of the implementation of this new selection process?

\section{IDENTIFyING THE PROBLEMS WITH NCS}

Through a process of cross-organizational discussions lead by DEC's procurement department, the following disadvantages were identified:

1. Increased bureaucratic workload: The existing selection method generates various administrative operations. In this process, PMs and public officials must engage in several contracts, conduct fee calculations, and manage multiple payments.

2. Project delays: Due to the need for arranging several contractual engagements with multiple consultants, the beginning of project design often suffers delays. While not being a primary source of delays, it was agreed that any novel selection method must consider its effect upon the project schedule.

3. Lack of cooperation: Under the existing selection method, consultants are selected individually and independently. When put together in a team, inharmonious relations may surface and have a negative impact on the design process.

4. Ambiguity of responsibility: The existing selection method does not define a single entity that is responsible for the design. When design errors occur, in many instances, it is not always clear where the responsibility for the error lies. Often, a "blame game" ensues where the consultant claims it is other consultants' fault. Such blame games have a detrimental effect on the working environment.

5. Outdated percentages in the existing $\mathrm{A} / \mathrm{E}$ fee standard: To ensure that the $\mathrm{A} / \mathrm{E}$ fee schedules are marketplace relevant, they are updated every few years. Updates are made through formal discussions with representatives from private consultant firms and by comparison to other procurement agencies. Historically, these update rounds always resulted in an increase in the fee schedules, even when technological advances in the field should have had an opposite effect. As a result, there was a general concern that the update process was biased in favor of the consultants.

\section{Proposed Change to the Selection Process}

In light of these issues, a novel method for the procurement of $\mathrm{A} / \mathrm{E}$ services was proposed and developed. The main principle of the new method is that consultant services would be selected according to a price-based tendering process for design team leaders. This method is therefore called Team Leader Selection (TLS). The winner of the tender is responsible for forming and leading a team of consultants that would act as their sub-contractors. Additional key features of the new selection method include the following:

1. Generally, architects are the design team leaders, as they both comprise the largest portion of fees, and are responsible for project geometry. Exceptions for this general rule are tenders 
for projects where a different consultant is most dominant, such as large infrastructure projects.

2. Tenders may be made for either specific projects, or as a fixed price agreement for a series of projects, where the winning team leader provides design services to all projects in a certain jurisdiction for the time period of the contract. Note that such fixed price agreements are referred to in the US as indefinite delivery/indefinite quantity (IDIQ) contracts.

3. Threshold criteria include the firm's size (capital and workforce), quality (licenses, ISO certification, etc.), and prior experience.

4. The DEC A/E standard fees are used as a basis for the competitive bid. In the tendering process, the competition is on the size of discount (or increase) to the standard fees. Team leaders submit a percent of increase or discount upon the basic fees for each consultancy discipline (architectural, electricity, water, energy, etc.). The bid's overall increase/discount percentage is calculated as the weighted average of the increase/discount percentages of the different disciplines. The exact weight of each discipline depends on the project type. The team leader with the lowest overall percentage bid wins the tender.

There are two types of tenders under TLS:

1. Fixed-agreement tenders: Tenders of this type cover all the projects of a certain year, region, and price range. The anticipated number of projects that are covered by this tender determines how many team leaders will be awarded the contract.

2. Single project tenders: This type of tender covers a single project and only one team leader can be awarded the contract.

There are three prices ranges for the fixed agreement tenders:

1. Small fixed-agreement tenders: For estimated design fees over USD85,000.

2. Medium fixed-agreement tenders: For estimated design fees in the range of USD85,000285,000 .

3. Large fixed-agreement tenders: For estimated design fees in the range of USD285,000430,000.

Single project tenders were used for projects above USD430,000. For clarity and comparability, all costs in Israeli currency (New Israel Shekel - NIS) are reported in USD. The average currency exchange rate of NIS to USD between January 2015 and January 2021 was approximately 3.5 NIS to 1.00 USD.

Note that with respect to bureaucracy reduction, the benefit from the use of fixed agreement tenders for A/E services is twofold. First, it obviates the need for direct contractual engagements with consultants from multiple disciplines. Second, a single contractual engagement with the lead firm allows hiring a design team for several projects.

To leave the PMs some flexibility, it was decided that the previous existing selection method, i.e. direct engagement with consultants on the basis of $\mathrm{A} / \mathrm{E}$ fees, will be maintained and used for limited consultancy services, or upon special PM request. However, the managements' directive was to minimize the use of the older NCS method to avoid a situation where PMs continue to work with the older method due to habit and/or risk aversion. The decision to maintain the old system along with the novel system allowed for an easy re-transition in case that the implementation of the novel method would fail.

It is important to emphasize that reducing design costs was neither the motivation nor the objective of the novel selection method. In fact, the opposite was assumed and for the bidding starting point, as a $5 \%$ increase was added to the $\mathrm{A} / \mathrm{E}$ standard fees. This addition was intended to compensate firms for managerial expenses associated with their role as team leaders. In contrast, the purpose of the novel system was to address the problems with NCS that were detailed in the previous section. In Table 1, these disadvantages are detailed alongside how they are addressed in the TLS method. 
Table 1. Disadvantages in the existing selection method, and their addressment in the novel selection method

\begin{tabular}{|l|l|l|}
\hline$\#$ & $\begin{array}{l}\text { Disadvantages in the existing } \\
\text { NCS A/E selection method }\end{array}$ & Novel A/E selection method \\
\hline 1 & $\begin{array}{l}\text { Increased bureaucratic } \\
\text { workload }\end{array}$ & $\begin{array}{l}\text { By direct contractual engagement with team leaders, a sig- } \\
\text { nificant reduction in bureaucratic workload may be } \\
\text { achieved. }\end{array}$ \\
\hline 2 & Project delays & $\begin{array}{l}\text { The design team leaders, being a private entity, are not } \\
\text { bound to many legal constraints. This allows them to en- } \\
\text { gage contractually considerably quicker than public agen- } \\
\text { cies. In addition, the fixed price agreements allow the win- } \\
\text { ning firm to provide services for a series of projects on im- } \\
\text { mediate demand. }\end{array}$ \\
\hline 3 & Lack of cooperation & $\begin{array}{l}\text { As the team leaders are responsible for selecting other con- } \\
\text { sultants as they please, cooperation is assumed to increase. }\end{array}$ \\
\hline 4 & Ambiguity of responsibility & $\begin{array}{l}\text { The team leaders are defined as the sole responsible entity. } \\
\text { Hence, they are highly incentivized to prevent design errors. }\end{array}$ \\
\hline 5 & $\begin{array}{l}\text { Outdated fee percentages in } \\
\text { the DEC A/E fee standard }\end{array}$ & $\begin{array}{l}\text { The competitive tendering process is assumed to correct for } \\
\text { biases in the A/E fee standard. }\end{array}$ \\
\hline
\end{tabular}

Prior to its execution, different concerns regarding the novel approach were raised:

1. PM status would be weakened as the overwhelming majority of consultants will not be hired directly by them. Additionally, PM personal preference and recommendations will cease to be a motivating factor for the team leader firms that will now compete solely on the basis of low price.

2. Existing firms are not accustomed to operating as lead contractors, and therefore they may fail to fulfil their contractual commitments.

3. Firms that are selected as team leaders will hire low quality consultants in order to increase profits. In turn, this will have a detrimental impact on project quality and success.

The latter concern was echoed by private consulting firm representatives, who cautioned that this change in policy has the potential of reshaping the private marketplace to such an extent that would have industry-wide consequences. Specifically, there was a concern that an industry divide would occur, where a small number of large firms would benefit at the expense of medium to small firms, which would eventually be driven out of business. Despite these concerns, during 2013, the first novel A/E tenders were published and the TLS method was implemented. The outcomes of this organizational shift are discussed in the following section.

\section{ORganizational CHANGE OUTCOMES}

\section{QUANTITATIVE OUTCOMES}

Recall, there were four tender types under TLS: one for single projects, and three standard fixed agreement tenders. The latter types were implemented on a triannual basis. Between 2013 and 2019, 276 projects were designed using this method, with final design fees amounting to a total of 29.94 million USD. The fact that the NCS fee system is used as a basis for TLS renders comparison between the two a straightforward task. The consistent discounts obtained via TLS demonstrate that this method has considerable saving potential. The discount percentages ranged between $1-14 \%$ with 
an average discount of $8.4 \%$. For large single projects, there were 56 tenders for which the winning discount bids ranged $5 \%$ to $36 \%$, with an average discount of $26.5 \%$. Results show that the larger the costs of the projects, the greater are the discounts of the winning bids.

We note that final project fees are computed as a percentage against actual costs. During construction, quantities and costs may change considerably compared to the initial cost estimation which served as the basis for the contractual engagement with the consultants. In addition, consultants may demand additional payments due to services requested beyond contractual obligations. As a result, final payments could be higher compared to the original tender offer.

The authors analyzed additional data from DEC regarding construction bids. There, a pendulum effect was identified, where the winning contractors bid well below project cost estimates in order to win the contract, but were ultimately paid above project cost estimate at completion. Thus, the contractor's behavior can be viewed as strategic and systematic. It is therefore questioned whether the novel cost-based selection method leads consultants to behave similar to contractors, and use various tactics (e.g., false claims) to compensate for their low offer.

In Table 2 we compare the initial and final fees of fixed agreement projects using TLS and the earlier NCS method. For each project, we compute the percent increase in fee between the initial assessment and final fees. For the TLS projects, the mean increase in fees is $28.2 \%$ (SD $=40.8 \%$ ), whereas for the NCS projects the percent increase is slightly lower $24.7 \%(\mathrm{SD}=31.9 \%)$. A two-sample unequal variance $\mathrm{t}$-test was conducted $(\mathrm{t}=1.35, \mathrm{p}=0.178, \mathrm{df}=472)$ and the difference between the two methods was not found to be significant. These results suggest that winning firms via the novel method do not subscribe to the pendulum effect identified in the construction realm. In other words, the competitive TLS method did not cause the winning consultant firms to bid in a strategic manner, similar to contractors.

Table 2. Winning discounts for fixed agreement tenders by type and region

\begin{tabular}{|l|c|c|c|}
\hline Method & $\mathrm{N}$ & Mean (SD) & Range \\
\hline TLS & 276 & $28.2 \%(40.8 \%)$ & {$[2.6 \%, 261 \%]$} \\
\hline NCS & 542 & $24.7 \%(31.9 \%)$ & {$[2.2 \%, 190 \%]$} \\
\hline
\end{tabular}

Table 2 also details the number of projects, $\mathrm{N}$, that was executed using each of the selection methods. The table reveals that the older approach has been used to a greater extent than the novel method. This finding demonstrates that direct hiring of consultants via the NCS method is still practiced widely, in contrast to the original intention of DEC management. Indeed, several PMs have demanded to continue hiring consultants using the NCS method, due to its perceived advantages. However, many of the A/E services are not provided in the context of project management, as consulting services are required for other tasks as well, such as land-use and master planning, supervision, etc. Therefore, this finding does not necessarily indicate that the majority of PMs generally prefer working with the older NCS method.

\section{QUALITATIVE OUTCOMES}

Following the quantitative data, which suggests that the novel selection method yields considerable savings to the public organization, it is important to examine additional qualitative effects. Specifically, it is important to assess the outcomes in light of the objectives and concerns as discussed in Table 1 . Table 3 lists the disadvantages which triggered the organizational change, and the perceived outcomes under the novel selection method. 
Table 3. Disadvantages in the existing selection method, and outcomes under the novel selection method

\begin{tabular}{|l|l|l|}
\hline$\#$ & $\begin{array}{l}\text { Disadvantages in the } \\
\text { existing NCS A/E } \\
\text { selection method }\end{array}$ & Novel TLS method outcome \\
\hline 1 & $\begin{array}{l}\text { Increased bureaucratic } \\
\text { workload }\end{array}$ & Bureaucratic workload reduction was achieved. \\
\hline 2 & Project delays & $\begin{array}{l}\text { On the one hand, PMs reported that the A/E fixed price agree- } \\
\text { ments allowed them immediate hiring, thus shortening the pe- } \\
\text { riod between initiation and design. } \\
\text { On the other hand, in many cases delays were caused due to } \\
\text { team leaders who failed to hire consultants according to con- } \\
\text { tractual deadlines. }\end{array}$ \\
\hline 3 & Lack of cooperation & $\begin{array}{l}\text { No apparent improvement was noticed. } \\
\text { In some cases, architects did not fully acknowledge their role as } \\
\text { team leaders, and limited their responsibility to the hiring of } \\
\text { consultants, while expecting the PM to take leadership. }\end{array}$ \\
\hline 4 & $\begin{array}{l}\text { Ambiguity of } \\
\text { responsibility }\end{array}$ & $\begin{array}{l}\text { As team leaders are defined as the sole responsible entity, ambi- } \\
\text { guity is eliminated by definition. } \\
\text { In terms of reduction of design errors, no apparent improve- } \\
\text { ment was noticed. }\end{array}$ \\
\hline 5 & $\begin{array}{l}\text { Outdated fee percent- } \\
\text { ages in the DEC A/E } \\
\text { fee standard }\end{array}$ & $\begin{array}{l}\text { The competitive tendering process brought a considerable re- } \\
\text { duction in overall design costs. } \\
\text { However, specific outdated service fees could not be identified. }\end{array}$ \\
\hline
\end{tabular}

Some of the concerns raised prior to execution were indeed found to be valid. Especially in the initial period of operation, many problems were encountered with the performance of the winning firms. This was manifested mainly by outcomes \#3 and \#4 given in Table 4.

In addition, PMs reported cases where consultants hired by the team leader performed poorly and seemed indifferent to their reputational damage. This problem can be a consequence of the nature of the novel TLS method, where individual consultants are not hired directly by the organization, and therefore are not incentivized to satisfy the PM. Additionally, the results of competitive tendering dictate the need for cost savings, thus it was anticipated that team leaders would hire low-quality consultants. Quality is indeed difficult to measure objectively, but nevertheless, a reduction in consultant quality was reported by many PMs.

In many cases, consultants who acted as subcontractors turned to DEC PMs and officials with complaints regarding oppression by the lead firms. From a legal perspective, DEC has no responsibility and authority in conflicts between contractors and subcontractors. Notwithstanding, in some cases, DEC PMs and officials acted as informal arbitrators and attempted to resolve such conflicts. During the years, modifications were made in the tendering procedure, aimed to alleviate the reported problems, amongst them:

- Setting a low bid threshold: In order to avoid cases where abnormally low bidders are rewarded contracts, a low bid threshold was employed. This threshold was defined as all bids that are lower by $15 \%$ compared to the median offer given by all team leaders. It was assumed that this threshold would reduce cases of low-quality design services. 
- Requiring bidders to state the identity of core consultants: In order to prevent cases where team leaders failed to hire consultants on time, or hired consultants that performed poorly, a contractual requirement was introduced where the team leader is demanded to state the identity of the core consultants in their proposal. For standard projects, the core consultants were defined as structural, electric, water, and air-conditioning engineers. For other consultants, which are less frequently needed, the team leader is not required to pre-determine their identity and may hire different consultants for each project.

- Addressing BIM technology: In the past years, similar to many other organizations, DEC established guidelines that require consultants to use BIM technology. In order to allow for the selection method to properly integrate this demand, contracts were updated to include requirements for BIM proficiency, as well as cost compensation for BIM use in specific projects. A review of the adoption of BIM by DEC, as well as other public agencies in the UK, is given by Gurevich and Sacks (2020).

- Integrating PM satisfaction as a future parameter for consultant selection: In order to develop a method where firms that consistently perform poorly can be disqualified from future tenders, it was proposed that PMs must provide feedback in the form of satisfaction surveys. However, although this decision was implemented, the results have not been used for actual due to legal and managerial conflicts regarding this measure.

As stated in Section 5, concerns were raised by various consultants that the shift in selection method would alter the design marketplace. A thorough examination of potential influence on the marketplace is beyond the scope of this paper. However, no major changes were observed, and most firms continued to work with DEC during the years that followed the reform.

\section{CONCLUSION AND LIMITATIONS}

In 2012, the Department of Engineering and Construction (DEC), a large Israeli public governmental agency, transitioned from an NCS approach for the selection of A/E services to a novel and competitive consultant selection method. The novel method is based on tenders for large architectural firms to act as lead contractors, responsible for hiring and managing the other consultants.

The novel method was found to bring significant savings in design expenses. In addition, the bureaucratic workload was reduced, due to the shift to contracting with team leaders rather than direct contracting with each of the consulting disciplines. In terms of impact on construction and contractor performance, data does not suggest that a substantial impact exists.

Project managers responded to the organizational shift with mixed reviews; some pointed to the advantage of shortening the time period between the demand and supply of $\mathrm{A} / \mathrm{E}$ services, while others mentioned the drawbacks of the novel selection method from their perspectives, such as less control over consultants, lower quality consultants, and internal conflicts between the design team leader with other consultants, a problem which seldom required the involvement of project manager and other DEC officials.

As a response, different modifications were made during the years following the transition, with two of the most notable being: (1) disqualification of overly low bids, and (2) pre-approval of the identity of the four predominant consultants.

The older NCS method was maintained and used alongside the novel selection method, rendering retransition a simple task. Nonetheless, the use of the novel system increased over the years and has become habitual. Overall, the current case study demonstrates that the shift from quality to costbased selection has meaningful advantages from a public agency's perspective.

With respect to work conducted by other researchers, the overall positive outcomes of the competitive selection method found in the current study are in line with the findings of Laryea et al. (2020) and are in contrast with the conclusion of Minato (2003), Christodoulou et al. (2004), and 
Akampurira and Windapo (2018). Differences in findings between researchers could be attributed to research limitations. Similar to the work undertaken by others, the current paper is subject to various cultural effects.

Additionally, the current study did not consider the effects of changes in the consultant marketplace that happened concurrently with the change in DEC's selection method. These include an increase in the number of large private-partnership projects (PPP) initiated by DEC and the expansion of the use of Building Information Modelling (BIM) methodology and software.

The final limitation is related to the data collected for this study. The pertinent quantitative data was difficult to collect and analyze, due to the manner of how the data is cataloged in the organization's ERP system. Consultant and construction service hiring are managed by different branches, and data is specified according to different organizational perspectives. Therefore, data collection and analysis at the organizational level is a cumbersome task. This matter is exacerbated by the fact that in construction projects it may take several months and even years from initial design to full completion. In this period of time, projects are frequently subject to changes in characteristics and quantity. Hence, it is more difficult to identify and interpret trends in expenses.

Looking to the future, rapid technological advances and cultural change are anticipated to alter the workplace environment profoundly. Hence, it is important to re-evaluate current selection methods and consultant fees, as well as data storage and analysis methods. In this regard, case studies provide an important source of knowledge for future discussion and decisions.

\section{REFERENCES}

Akampurira, E., \& Windapo, A. (2018). Factors influencing the quality of design documentation on South African civil engineering projects. Journal of the South African Institution of Civil Engineering, 60(3), 41-48. https://doi.org/10.17159/2309-8775/2018/v60n3a4

American Society of Civil Engineers. (2012). How to select and work effectively with consulting engineers: Getting the best project. Manual of Practice No. 45. https://doi.org/10.1061/9780784411957

Awwad, R., \& Ammoury, M. (2019). Owner's perspective on evolution of bid prices under various price-driven bid selection methods. Journal of Computing in Civil Engineering, 33(2).

https://doi.org/10.1061/(ASCE)CP.1943-5487.0000803

Carr, P. G., \& Beyor, P. S. (2005). Design fees, the state of the profession, and a time for corrective action. Journal of Management in Engineering, 21(3), 110-117. https://doi.org/10.1061/(ASCE)0742597X(2005)21:3(110)

Christodoulou, S., Griffis, F. H., Barrett, L., \& Okungbowa, M. (2004). Qualifications-based selection of professional A/E services, Journal of Management in Engineering, 20(2), 34-42. https://doi.org/10.1061/(ASCE)0742-597X(2004)20:2(34)

Feldmann, M. L., Chrusciel, D., Pohlmann, A., Shelley, M. C., McCool, K., Morton, A. D., \& Ahoy, C. K. (2008). Architectural and engineering fees from the public institutional perspective. Journal of Management in Engineering, 24(1), 2-11. https://doi.org/10.1061/(ASCE)0742-597X(2008)24:1(2)

Gurevich, U., \& Sacks, R. (2020). Longitudinal study of BIM adoption by public construction clients. Journal of Management in Engineering, 36(4). https://doi.org/10.1061/(ASCE)ME.1943-5479.0000797

Han, S., Love, P., \& Peña-Mora, F. (2013). A system dynamics model for assessing the impacts of design errors in construction projects. Mathematical and Computer Modelling, 57(9-10), 2044-2053. https://doi.org/10.1016/i.mcm.2011.06.039

Laryea, S., Watermeyer, R., \& Govender, N. (2020). The influence of fees on the quality of professional services in South Africa. Proceedings of the Institution of Civil Engineers - Management, Procurement and Law, 111. 
Ling, F. Y. Y. (2004). Consultancy fees: Dichotomy between A/E's need to maximize profit and employers' need to minimize cost. Journal of Professional Issues in Engineering Education and Practice, 130(2), 120-123. https://doi.org/10.1061/(ASCE)1052-3928(2004)130:2(120)

Löwstedt, M., \& Räisänen, C. (2012). 'Playing back-spin balls': Narrating organizational change in construction. Construction Management and Economics, 30(9), 795-806. https://doi.org/10.1080/01446193.2012.693189

Manzoni, B., \& Volker, L. (2017). Paradoxes and management approaches of competing for work in creative professional service firms. Scandinavian Journal of Management, 33(1), 23-35. https://doi.org/10.1016/j.scaman.2016.10.002

Minato, T. (2003). Design documents quality in the Japanese construction industry: Factors influencing and impacts on construction process. International Journal of Project Management, 21(7), 537-546. https://doi.org/10.1016/S0263-7863(02)00083-2

Ogbu, C. P., \& Imafidon, M. O. (2021). Influence of selection criteria on clients' satisfaction with construction consultancy services in Nigeria. Journal of Engineering, Design and Technology. https://doi.org/10.1108/JEDT02-2021-0081

Shash, A. A., \& Ajairi, F. S. (2021). An A/E pre-qualification model based on the quality function deployment method. Research Journal of Advanced Engineering and Science, 6(1), 237-247.

Sporrong, J. (2011). Criteria in consultant selection: Public procurement of architectural and engineering services. Construction Economics and Building, 11(4), 59-76. https://doi.org/10.5130/AJCEB.v11i4.2297

Sporrong, J., \& Kadefors, A. (2014). Municipal consultancy procurement: New roles and practices. Building Research \& Information, 42(5), 616-628. https://doi.org/10.1080/09613218.2014.900260

Steiner, R., Kaiser, C., \& Reichmuth, L. (2018). Consulting for the public sector in Europe. In E. Ongaro, \& S. Van Thiel (Eds.), The Palgrave handbook of public administration and management in Europe (pp. 475-495). Springer. https://doi.org/10.1057/978-1-137-55269-3 25

West, D. C. (1997). Purchasing professional services: The case of advertising agencies. International Journal of Purchasing and Materials Management, 33(2), 2-9. https://doi.org/10.1111/j.1745-493X.1997.tb00025.x

Wong, C. H., Holt, G. D., \& Harris, P. (2001). Multi-criteria selection or lowest price? Investigation of UK construction clients' tender evaluation preferences. Engineering, Construction and Architectural Management. 8(4), 257-271. https://doi.org/10.1046/j.1365-232x.2001.00205.x 


\section{AUTHORS}

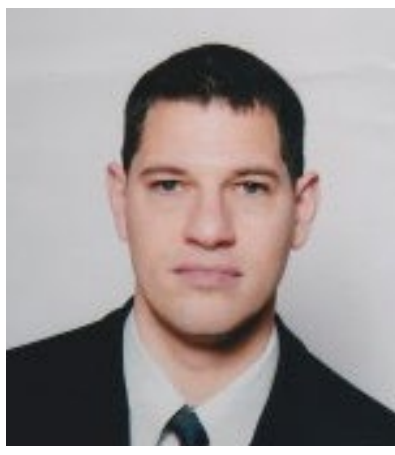

Dr. Amichai Mitelman is a faculty member in the Department of Civil Engineering in Ariel University. He holds a Ph.D. and an MSc. in Mining Engineering from the University of British Columbia, an MA. in Law, and a B.Tech. in Civil Engineering.

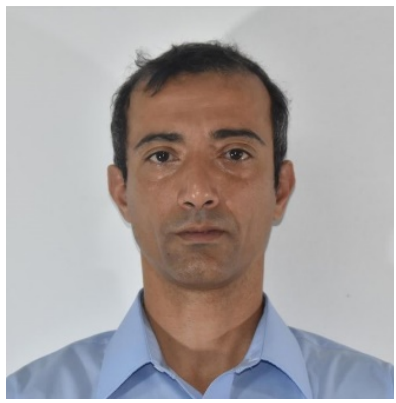

Dr. Yahel Giat is a tenured faculty member in the Department of Industrial Engineering and Management in the Jerusalem College of Technology. He holds a Ph.D. and an MSc. in Industrial Engineering from the Georgia Institute of Technology, an MSc. in Economics, a B.Sc. in Electrical Engineering, and B.A. in Computer Sciences from the Israel Institute of Technology. 